\title{
Effects of Genre Based Approach (GBA) In EFL Reading Comprehension and Writing'
}

\author{
Efectos del enfoque basado en los Géneros Textuales \\ (GBA) en la comprensión lectora y escritura del inglés \\ como lengua extranjera
}

\author{
Sindy Johana Montero-Arévalo ${ }^{2 *}$ \\ Universidad Popular del Cesar, Colombia
}

\begin{abstract}
The present paper puts under examination the effects of Genre Based Approach (GBA) on $9^{\text {th }}$ grade students from a city in the Caribbean coast of Colombia. The purpose of the study is to analyze how GBA affects reading comprehension and writing by comparing the students' results before and after the execution of the approach. GBA was implemented in six sessions using instruments for data collection that included tests, questionnaires and interviews. The genres selected for the study were anecdotes and recounts, which are the type of texts used in the English section of national exams in Colombia. The overall findings show that students' reading comprehension, writing, motivation and autonomy improved after the implementation of GBA; as a result, the students were able to understand, explain and recreate the genres that were part of the study.
\end{abstract}

Keywords: GBA; genre awareness; reading comprehension; writing; autonomy

\section{Resumen}

Este documento examina los efectos del enfoque basado en los géneros textuales (GBA) en estudiantes de noveno grado provenientes de una ciudad en la costa caribe colombiana. El estudio tiene como propósito analizar cómo afecta el GBA la compresión lectora y la escritura de los estudiantes, para esto fueron contrastados los resultados de los estudiantes antes y después de la aplicación del enfoque. El GBA se implementó durante seis sesiones utilizando exámenes, cuestionarios y entrevistas con el propósito

1 Received: july 31st 2018/ September 4th 2019

2 louper_10@hotmail.com 
de reunir la información necesaria. Los géneros textuales utilizados en estudio fueron anécdotas y recuentos, debido a que son los tipos de textos que hacen presencia en la sección de inglés de los exámenes nacionales en Colombia. Los resultados generales muestran que la compresión lectora, escritura, motivación y autonomía de los estudiantes aumentaron al completar las sesiones donde fue implementado el GBA; como consecuencia, los estudiantes comprendieron, explicaron y recrearon los géneros textuales utilizados en el estudio.

Palabras Clave: enfoque; géneros textuales; comprensión lectora; motivación; autonomía

\section{Resumo}

Este documento examina os efeitos do enfoque baseado nos gêneros textuais (GBA) em estudantes de primeiro ano do ensino médio provenientes de uma cidade no litoral caribe colombiana. O estudo tem como propósito analisar como afeta o GBA a compreensão leitora e a escritura dos estudantes, para isto foram contrastados os resultados dos estudantes antes e depois da aplicação do enfoque. O GBA se implementou durante seis sessões utilizando provas, questionários e entrevistas com o propósito de reunir a informação necessária. Os gêneros textuais utilizados em estudo foram anedotas e recontos, devido a que são os tipos de textos que fazem presença na seção de inglês dos exames nacionais na Colômbia. Os resultados gerais mostram que a compreensão leitora, escritura, motivação e autonomia dos estudantes aumentaram ao completar as sessões onde foi implementado o GBA; como consequência, os estudantes compreenderam, explicaram e recriaram os gêneros textuais utilizados no estudo.

Palavras Chave: enfoque; gêneros textuais; compreensão leitora; motivação; autonomia 


\section{Introduction}

7 he difficulty in reading texts has been an object of study, and for several decades, researchers have claimed diverse causes for lack of reading comprehension. Chambliss (1995) states that one of the reasons for low levels of understanding is the absence of exposure of students to readings with different structure than narrative. Scholars around the world have implemented an approach that exposes the students explicitly to the text structure, yielding positive results. This approach has been used in Colombia in order to improve reading comprehension in students. It is the case of Genre Based Approach (henceforth GBA), which have had positive results in students, increasing their understanding of texts. However, the GBA is still unknown in Colombia, due to few studies that have been dedicated to implement it.

Overall results in GBA studies revealed improvement in students' comprehension and motivation for reading. It is feasible to believe that the implementation of GBA in Colombia may facilitate the development of literacy skills in order that the students have a deeper understanding of written texts. It also will have an impact in national tests, but beyond that, reading comprehension is not focusing on an exam or an ability to answer correctly. Reading comprehension is a life skill that creates thinking citizens and potential writers that can push forward a country.

The interest behind developing this research was born when the teacher realized that her group of students presented problems during reading comprehension activities. A significant percentage of students were not able to understand the texts and struggle when they had to answer questions from different levels of comprehension, including questions directly mentioned in the text.

\section{Previous literature}

Reading encompasses more than decoding characters in a text; it implies the interpretation of what an author intends to say to an audience. In this order of ideas, reading is not possible without comprehension. According to Wallace (2001) "Comprehension is the form of the presentation of text followed by post-reading questions on the text" (p. 26). It is important to clarify that every reader has a personal interpretation of a text. Nevertheless, comprehension questions are present in many published materials in an effort to develop reading skills (Williams \& Moran, 1989).

Reading comprehension-based approaches have been created taking a stance in controversy whether a text has one meaning or multiple meanings determined by the reader (Masuahara, 2013). Some authors suggest that the real 
meaning is the one intended by the author and the efficiency of comprehension is determined by the interpretation of this meaning (Williams, 1983). On the other hand, Widdowson (1979) states that the meaning will diverge from reader to reader depending on several factors. We can conclude that every text written has an intention and an audience, and readers possess different points of view, backgrounds and reactions. However, it is essential for a reader to be able to understand the intention of the writer, the context of the text, the type of text, the audience that will read it and interpret the information provided by the author with the aim of creating a personal opinion of the text.

The understanding of a type of text requires establishing the patterns that master the text and the features that differentiate that specific structure from others. These patterns are named genres. Genre is a term used for categorizing different types of text (Hyland, 2004). According to Cope and Kalantzis (1993), "Genre is a term used in literacy pedagogy to connect the different forms texts take with variations in social purpose." (p. 7). So, genre not only refers to the grammatical structures of texts, but the social contexts where they are performed. Cope and Kalantziz (1993) also point out that "Genres are textual interventions in society; and society itself would be nothing without language in all its patterned predictability" (p. 7). Each society has established patterns where genres are used according to specific circumstances and culture. According to Martin and Rose (2008), genres are considered as staged, goal oriented social processes. They are considered staged due to the fact that there are several phases to accomplish an objective, genres are also goal oriented because there is a desire for obtaining a result and finally social, since every writer directs their text to a specific audience. In this regard, genres show us more than how a text is conformed; it presents us the purpose of the writer, their society customs and patterns.

Martin and Rose (2008) state that "genres are defined as a recurrent configuration of meanings and that these recurrent configurations of meaning enact the social practices of a given culture" (p. 5). This means that genres have specific uses for particular contexts, and there exist several categories that are grouped according to the genre's purpose. When a purpose needs to be established, the writer has to take some decisions, they have to set their intention, this decision will place the writer in one category that is followed for several choices, which will end in one specific genre inside a general one.

The recognition of the stages allows the reader to identify the intention of the writer and permits that the reader relates texts with similar structure. In writer's case, they can set the intentions of their text and follow the stages that are established. One approach that uses the recognition of types of text as a strategy for reading comprehension is the GBA. 
The structure of texts changes depending on the culture. Nevertheless, there are patterns that main types of text use. According to Farrell (2009), types of text can be classified into fiction (novels, short stories, plays and poetry) and nonfiction (essays, reports and articles), as the technology becomes part of the culture new genres appeared as memos, text messages and emails with their own characteristics and structures that can be easily identified. The awareness of the structure of different types of texts, its features and its rules can help the learners to comprehend better and recall the contents of a text while the learners develop their writing skills (Farrell, 2009).

Rose (2008) defines six steps for the reading learning cycle. First, prepare before reading, "orients students to the genre and field of the text" (Rose, 2008 p. 16). The purpose of this step is the students understand the text in general terms. In other words, what the text is about, the context and the unfamiliar words. The second stage, detailed reading, is when the "teacher supports all students to read each sentence in a short passage" (Rose, 2008 p. 16). It implies reading aloud the text and the conversion of sentences into simpler ideas for the students. In the third step, preparing for writing, the students "plan exactly what they are going to write, based closely on the passage they have studied in detailed reading" (Rose, 2008 p. 16). In this point, the teacher encourages brainstorming for new ideas based on the features that the students identified on the last stage with as a means to collect ideas for a new text.

The step following the collection of ideas is joint rewriting, where "the teacher supports the class to write a new text that is patterned on the reading text" (Rose, 2008 p. 16). The teacher in collaboration with the students create a new text created based on the ideas that the students provided and later this text will be similar to the students' writing. In the individual rewriting or fifth stage "the students practice writing a new text using the same patterns as the reading and joint rewriting texts" (Rose, 2008 p. 16). During this particular time, the students have the opportunity to work on their own and allows the teacher to support the students' texts as preparation for the final stage. Finally, independent writing is when "students use what they have learnt from the preceding stages to write an independent text" (Rose, 2008 p. 16). In this final level, the students write a text that may have a different topic but using the same genre worked previously. While students write their texts, they are conscious of the intention of the text type and will be able to identify the different stages 88 inside the text, its features that may facilitate the comprehension of texts with the same genre.

The six stages mentioned above, summarize the GBA which has been considered as "main institutionalized alternative to process pedagogy currently on offer" (Cheng, 2006). Scholars are always in the pursuit of solutions of students' needs, in consequence, pedagogies will appear to fit new necessities of students and Genre approach is now one that is currently in use. According 
to Lee (2012), Genre approach assumes that students learn best when they are exposed explicitly to the structure of texts, its language and its structural features of different types of texts that they need to learn to read and write.

In 2008, Rose classified the principal genres, its subgenres, purposes and stages. The focus of this study is the stories genre, specifically anecdotes and recounts. According to Rose (2008) "the purpose of a recount is to recount series of events, so its stages include an orientation and a record of events" (p.15). This genre attempts to describe situations according to their sequence of their execution. This is one example of a recount:

1936 it was. I would have been five. We went visiting Ernabella the day the police came. Our greatuncle Sid was leasing Ernabella from the government at that time so we went there. We had been playing all together, just a happy community and the air was filled with screams because the police came and mothers tried to hide their children and blacken their children's faces and tried to hide them in caves. We three, Essie, Brenda and me together with our three cousins ... the six of us were put on an old truck and taken to Oodnadatta which was hundreds of miles away and then we got there in the darkness.

My mother had to come with us. She had already lost her eldest daughter down to the Children's Hospital because she had infantile paralysis, polio, and now there was the prospect of losing her three other children, all the children she had. I remember that she came in the truck with us curled up in the fetal position. Who can understand that, the trauma of knowing that you're going to lose all your children? We talk about it from the point of view of our trauma but - our mother - to understand what she went through, I don't think anyone can really understand that. It was 1936 and we went to the United Aborigines Mission in Oodnadatta. We got there in the dark and then we didn't see our mother again. She just kind of disappeared into the darkness. I've since found out in the intervening years that there was a place they called the natives' camp and obviously my mother would have been whisked to the natives' camp. There was no time given to us to say goodbye to our mothers. (Australian Human Rights Commission, 2010, p. 111)

The second emphasized genre in this research is anecdotes. Martin and Rose (2008) state that "the point of an anecdote is to share an emotional reaction. To this end, anecdotes present a sequence of events that is out of the ordinary and conclude with the protagonist's reaction to the events" (p. 52). One identifier of this type of text is the complication followed by a reaction during the narration. Following an example of an anecdote: 
My name is Millicent D. I was born at Wonthella WA in 1945. My parents were CD and MP, both 'halfcaste' Aborigines. I was one of seven children, our family lived in the sandhills at the back of the Geraldton Hospital. There was a lot of families living there happy and harmonious. It was like we were all part of one big happy family.

In 1949 the Protector of Aborigines with the Native Welfare Department visited the sandhill camps. All the families living there were to be moved to other campsites or to the Moore River Aboriginal Settlement. Because my parents were fair in complexion, the authorities decided us kids could pass as whitefellas. I was four years old and that was the last time I was to see my parents again. Because my sisters were older than me they were taken to the Government receiving home at Mount Lawley. My brother Kevin was taken to the boys home in Kenwick. Colin and I were taken to the Sister Kate's Home. We were put in separate accommodation and hardly ever saw each other. I was so afraid and unhappy and didn't understand what was happening. (Australian Human Rights Commission, 2010, p. 100)

The clear exposure to text structures is the methodology that many researchers around the world are applying to students from different cultures and backgrounds. Lubawski and Sheehan applied in 2010 GBA to tenth grade students in a public school in Massachusetts. The problem that teachers identified was that the students were not able to understand the written material received in class so they carried out a research with the objective to answer what strategies can be used in order to improve students reading comprehension across different genres. The researchers collected data through observations in the classroom, tests and students' feedback. The results showed that students become more successful and confident in their reading abilities, supporting the statements of some researchers:

GBA to teaching and learning writing seems to be relevant for the students with low competencies and low motivation. It really guides the students to write from the very simple or dependent steps to independent steps. It also promotes and facilitates the student finally to learn in autonomous learning way (Dirgeyasa, 2016, p. 50)

GBA has had positive results in students' reading comprehension and writing, its stages allow the teacher to work in collaboration with their students and lead them to their autonomy, diminishing their participation in the students' work as gradually as the students embrace their independency. The improvement of reading and writing skills suits two important needs of our students that may lead to important achievements in the future of Colombian professionals. 


\section{Methodology}

Classrooms are not homogeneous scenarios where strategies will yield the same result, without giving importance to students' background or context. Considering that each group of students has different lacks and needs, the type of study selected was qualitative research. Sandoval (1996) states that "Due to that there is not possibility to predict the reaction of the group to the GBA, qualitative research allows that the instruments for collecting data be in accordance with the characteristics of each situation. (p. 125)."

The main purpose of the study is to analyze the way GBA affects reading comprehension and writing in EFL students from 9th grade. We chose Action Research to identify the reactions of the students during and after the execution of the GBA. Cohen and Manion (1994) define Action Research as 'a smallscale intervention in the functioning of the real world and a close examination of the effects of such an intervention' (p. 186). In this study the researcher interfered in a real-world situation, which may yield favorable or negative results, either case with the application of Genre-based the students might improve their reading comprehension skills and in this way other aspects of life might be facilitated for them.

\section{Setting and Participants}

This study took place in a private bilingual school in Valledupar, Colombia. The class selected had 36 students; all of them were in $9^{\text {th }}$ grade between 13 and 15 years old. The school was recently recognized as bilingual consequently, the group selected did not have many hours of English until a few years ago. Therefore, the English level of most students is A1 or less, which is lower than presumed for ninth graders.

All the students participated in the written texts, questionnaires but only eight students took part in the interviews. One teacher was responsible for planning, conducting and assessing the students during the implementation of the GBA.

\section{Instruments}

The first instrument used was a pre-test. It had two short readings (one anecdote and one recount), one open question about the main idea of the text and multiple-choice questions related to literal information, inference and interpretation.

After the pre-test, the teacher implemented a structured interview in which she asked the students to explain their answers. The structured interview is one in which the content and procedures are organized in advance. This 
means that the sequence and wording of the questions are determined by means of a schedule and the interviewer is left little freedom to make modifications. Where some leeway is granted to her, and it is also notified in advance. It is therefore characterized by being a closed situation (Cohen, Manion and Morrison, 2003).

The structured interviews avoid distractions of the teacher in terms of doubts about the next question. It also allows the teacher to pay more attention to the students' answers.

Besides the interviews, the handouts that the teacher gave to the students were adapted from Reading to Learn (Rose, 2008). The structure of the copies provides guidance to the students during the process of writing and after the independent writing phase, the teacher used a rubric to revise the stages of GBA in students' writing. Stevens and Levi (2013) state that "Rubric saves time, provide timely, meaningful feedback for students, and have potential to become and effective part of the teaching process" (p.17). The rubric used in the study was based on the 'three-level rubric' (Stevens and Levi, 2013) which format enables the teacher to verify the mastering of students learning about texts patterns.

Table 1. Instruments and its relation to the research objective.

\begin{tabular}{|l|l|l|}
\hline \multicolumn{1}{|c|}{$\begin{array}{c}\text { Technique/ } \\
\text { instrument }\end{array}$} & \multicolumn{1}{|c|}{ Instrument's objective } & \multicolumn{1}{c|}{ Research objective } \\
\hline $\begin{array}{l}\text { Pre-Test (Written } \\
\text { and oral) } \\
\begin{array}{l}\text { Final Test (Written) } \\
\text { Oral test }\end{array}\end{array}$ & $\begin{array}{l}\text { Analyze the answers of the } \\
\text { students, in order to know } \\
\text { if there is comprehension of } \\
\text { the reading or not. }\end{array}$ & $\begin{array}{l}\text { - Analyze the way } \\
\text { Genre Based Approach } \\
\text { (GBA) affects reading } \\
\text { comprehension in EFL } \\
\text { students of } 9^{\text {th }} \text { grade. }\end{array}$ \\
\hline Rubric & $\begin{array}{l}\text { Check if the students } \\
\text { follow the steps of genre in } \\
\text { their writing. }\end{array}$ & $\begin{array}{l}\text { - Characterize the writing of } \\
\text { students of 9th grade after the } \\
\text { implementation of GBA. }\end{array}$ \\
\hline $\begin{array}{l}\text { Interviews/ } \\
\text { Questionnaire } \\
\text { Virtual questionnaire }\end{array}$ & $\begin{array}{l}\text { Check level of acceptation } \\
\text { in the students. }\end{array}$ & $\begin{array}{l}\text { - Determine students' } \\
\text { perception about the } \\
\text { methodology implemented. }\end{array}$ \\
\hline
\end{tabular}

At the end of the process, the teacher implemented a final test which format was very similar to the pre-test; both included oral evaluations with random students. This test was used in order to compare students' comprehension before and after the study. 
Besides the written test, the teacher selected and recorded four random students for an oral test that included open questions about inference, vocabulary and literal information of two texts (one recount and one anecdote).

Finally, in order to evaluate students' attitude towards the study, the teacher applied two questionnaires. First, a structured questionnaire where the students had to evaluate the course from one to five, being one the lowest score and five the highest. This questionnaire allowed seeing patterns in students' answers. The second questionnaire was an "open invitation to write what one wants" (Cohen, Manion and Morrison, 2003 p. 248) the open questionnaire enables the students to respond in their own terms and in an anonymous way.

\section{Procedure}

In some sessions, the activities took more time than expected, due to the class was interrupted by coordinators who had to spread information about a parent meeting, teachers who wanted to clarify an assignment or students that were in charge of providing some information related to school events. These situations were common in the school and caused that teacher had to reorganize the activities. However, it was possible the achievement of the activities planned as it follows:

Session zero: Before the application of the project, the teacher applied a pre-test with the purpose of contrasting the level of comprehension before and after the study.

Session one: The teacher explicitly explains the students the structures of the texts, its uses and the features that characterizes, in order that the students identified the different text-types.

Session two: The students had to reorganize texts according to the structure and features.

Session three: The teacher writes in collaboration with the students a recount and an anecdote following their structure and features.

Session four: The students write independently a recount and an anecdote.

Session five: The teacher implemented a final written test, questionnaires and interviews. 
Table 2. Description of GBA sessions.

\begin{tabular}{ll}
\hline Session & \multicolumn{1}{c}{ Description } \\
Zero & Pre-Test \\
One $\quad \begin{array}{l}\text { Before the presentations of the readings, the } \\
\text { teacher practice through games the key } \\
\text { vocabulary of the texts then, the teacher shows } \\
\text { different texts and ask the students to identify } \\
\text { the aspects that distinguish them in order to } \\
\text { identify the parts of the text. }\end{array}$
\end{tabular}

Two With the same categ ories of texts, the students reorganize readings considering the sequence learnt in session number one. After, the teacher shows the different features of each type of text

Three The teacher and the students give ideas for a recount and an anecdote, then each student writes their text following the steps of each reading.

Four The students write their own recount and anecdote without help.

Five The students did a final test and we selected some of them for interviews, so they expressed their points of view and the Blah, difference between what they did before the approach and after.

\section{Graphic organizer}

test
Orientation

Recount of events

Brainstorming

\section{Results}

This research attempts to investigate the effects of GBA on $9^{\text {th }}$ grade students' reading comprehension and writing. The results of this study support previous studies carried out in EFL students and presented positive effects of GBA in reading comprehension of non-native English speakers. Some researchers carried out these studies in similar contexts that included large groups and homogeneous backgrounds (Barletta, Moreno \& Toloza, 2013; Sadeghi, Taghi, \& Hemmati, 2013). 
In the study, the students were able to identify the stages of a text and to identify the purpose of each story. We noticed that in the results, the rising of students' confidence when they answered the oral test at the end of the study, they were sure of their answers that were accompanied with arguments that supported their ideas. We also acknowledged the development of their selfreliance during the independent writing. The students during the re-writing were very teacher-depended; they were not sure about what they were writing and asked for approval from the teacher in every part of the process.

According to Feez, (1998) in the re-writing stage the teacher should gradually diminish the participation in the text construction so that the students are able to deal with the structure of the texts independently. During the independent writing, there were almost no questions for the teacher and the students completed the writing by themselves. In this stage, it was possible to perceive the increase of students' confidence since the re-writing stage. Previous studies by Haria (2011) and Lubawski and Sheehan (2010) described the increasing confidence in students and teachers as one positive effect of the implementation of GBA and the enlargement of critical thinking in students.

Additionally, one effect that was evident in this study is students' motivation. During the interviews, some students expressed that at the beginning of the course they were not interested, because the activities were not graded. However, during the lessons, the students that were not motivated to do the activities became active participants and some of them were volunteers for the questionnaire's interview, where they talked about their change and their improvement since the beginning of the sessions. In the phase where the students' demonstrated to be more motivated was when they were able to express ideas to construct a text. Rose (2008) suggests the brainstorming when attempting to improve the understanding of stories, he also stated that the ideas provided by the students are closer to what the students will write by themselves. The appropriation of the text allows the students to create a link between the text and them, and it facilitates their understanding and their confidence in writing texts with the same structure. During this stage, the students that were not very interested in the course, started to provide ideas for the text's construction and developing the next stages of the course.

The study focused on three main aspects: Analyze the way GBA affects reading comprehension in EFL students of $9^{\text {th }}$ grade, characterize the writing of students of 9th grade after the implementation of GBA, and determine students' perception about the methodology implemented.

Through the implementation of interviews and test, it was possible to determine how GBA affected students' reading comprehension. The results demonstrated that the students were able to answer literal questions easily. However, the questions related to inferring words from the context were 
complicated for them. In the pre-interviews the students mentioned strategies that might help them in this type of questions. Nevertheless, when they explained the reasons for selecting the words, the students guessed or expressed that they were confused. After the GBA, in the final oral test, the questions were open and in the inferring questions, most of the students were able to relate an unknown word to a synonym that they had to infer from the text.

On the other hand, the writing skills improved in students from the rewriting to the independent writing. First, in the re-writing the students followed a model and included stories related to the school and people they know. In the independent writing stage, the familiar places diminished, and the students created fictional stories with invented characters and personal desires. They also included more features of anecdotes and recounts that provided a more complex text than the example given by the teacher and the re-writing.

Finally, the students expressed positive answers related to the course, the methodology and the instructor. The students coincided that the course helped their reading comprehension, that what they learned was useful for their development as persons and students. Additionally, they considered that doing the activities step by step facilitated the work for them. On the other hand, one student mentioned the noise as the main problem during the course, due to the heavy traffic close to the institution. Nevertheless, these conditions do not belong to this group only, the setting around school is usually not appropriate for concentration and production. Despite this environment is not adequate for any of the participants in the classroom, it is the condition of many classrooms in Colombia and is completely out of our control.

\section{Conclusions}

In global terms, the results of this study indicate that GBA has a positive effect on reading comprehension and writing on EFL students from ninth grade. The overall results also show that students have a better understanding of texts and were able to infer meanings from the readings. Furthermore, students' writing was aligned to the text types implemented in the study. In this part of the process, the students worked independently, and the findings described that most of the students used the structure of anecdotes and recounts. In addition, some students created more detailed situations in the stories than the ones that the teacher showed as examples. Finally, the results of the questionnaire indicate that students' perception of the methodology implemented was positive, including students that changed their idea of the study from a negative to a positive reaction. These reactions prove that GBA has an important impact on students' abilities and its use may cause a difference in Colombian students from a non-literary country to an ascent in readers and 
potential writers. Additionally, GBA allows the teacher to guide the students to a point where they can work independently and develop autonomy and selfconfidence in the actions that they perform.

It was also notable in some students that they had the knowledge or a similar word that could lead them to answer correctly the questions of the test, but they were not able to use that knowledge in their favor. Not all the results in the study were positive, even though the students obtained better scores in the written texts, in the oral interviews the students still struggle with the usage of pronouns as well as they did not know at the end of the course, the purposes of the texts that were explained. These negatives outcomes demonstrate the immense necessity of our intervention in favor of students' improvement.

Although further work is required on how we can use GBA in more complex genres related to different areas as science, social studies, literature etc. It is also needed research related to how genre affects other abilities besides reading and writing and how the GBA affects students' and teachers' performance. Additionally, during this study we paid very little attention to students' habits of reading. Therefore, further research can be implemented on how genre-based approach can cultivate reading habits in the students. In this way, we might encourage that the students develop autonomy for selecting texts and in consequence, the expansion of their exposure to different genres and their abilities to understand them. 


\section{References}

Australian Human Rights Commission,. (2010). Bringing them home: The "Stolen children" report (1997).

Barletta, N., Moreno, F., Toloza, H. (2013). A coaching experience to assist the teaching and learning process of reading and writing in the school context, Zona próxima [Electrónica], 19, 39-55.

Chambliss, M. J. (1995). Text Cues and Strategies Successful Readers Use to Construct the Gist of Lengthy Written Arguments. Reading Research Quarterly,30(4), 778-807.

Cheng, A. (2006). Understanding learners and learning in ESP genre-based writing instruction. English for Specific Purposes, 25(1), 76-89.

Cohen, L. \& Manion, L. (1994) Research Methods in Education (4th ed.). London: Routledge.

Cohen, L., Manion, L., \& Morrison, K. (2003). Research methods in education (5th ed.). London: RoutledgeFalmer.

Cope, B., \& Kalantzis, M. (1993). The Powers of literacy: A genre approach to teaching writing. Pittsburgh: University of Pittsburgh Press.

Dirgeyasa, I. W. (2016). Genre-Based Approach: What and How to Teach and to Learn Writing. English Language Teaching, 9, 9, 45.

Farrell, T. S. C. (2009). Teaching reading to English language learners: A reflective guide. Thousand Oaks, Calif: Corwin Press.

Feez, S., (1998). Text-based syllabus design. Sydney: National Centre for English Language Teaching and Research.

Haria, P. D. (2011). The effects of teaching a genre-specific reading comprehension strategy on struggling fifth grade students' ability to summarize and analyze argumentative texts. University Of Delaware.

Hyland, K. (2004). Genre and second language writing. Ann Arbor, MI: The University of Michigan Press.

Lee, M. (2012). Teaching genre-based writing to Korean high school students at a basic level.

Lubawski, M., \& Sheehan, C. (2010). Reading Comprehension across Different Genres: An Action Research Study.

Martin, J. R., \& Rose, D. (2008). Genre relations: Mapping culture. London: Equinox Pub. 
Rose, D. (2008). Reading to Learn. 2008 edition. David Rose 2008.

Sandoval, C. C. A. (1996). Investigación cualitativa. Santafé de Bogotá: Icfes.

Stevens, D. D., \& Levi, A. (2013). Introduction to rubrics: An assessment tool to save grading time, convey effective feedback, and promote student learning. Sterling, Virginia: Stylus.

Wallace, C. (2001). "Reading". In R. Carter \& D. Nunan (eds.) The Cambridge Guide to Teaching English to Speakers of Other Languages (pp. 21-27). Cambridge: Cambridge University Press.

Widdowson, H. G. (1979). Teaching language as communication. Oxford: Oxford Univ. Press.

Williams, E. (1983). Communicative reading. In Johnson \& Porter (1983).

Williams, E. \& Moran, C. (1989). Reading in a foreign language at intermediate and advanced levels with particular reference to English. Language Teaching, 22, 217-28. 


\section{Author}

Sindy Johana Montero-Arévalo M.A In English Language teaching from Universidad del Norte and Modern Languages Teacher from Universidad Popular del Cesar. Teacher and tutor for local English programs for public and private universities. She has worked at Pearson, an international publishing house, as a teacher and she also has developed diverse projects related to technological resources.

ORCID: https://orcid.org/0000-0002-0450-3268 